\title{
Comparision of Different Raw Densities and Board Thicknesses in the Production of Enzymatically Bonded Fiberboards
}

\author{
Alexander Kirsch ${ }^{1}$, Patrick Reuter ${ }^{1}$, Alireza Kharazipour ${ }^{2}$ \& Markus Euring. ${ }^{1}$ \\ 1 Department of Molecular Wood Biotechnology and Technical Mycology, Georg-August-University of \\ Goettingen, Germany \\ ${ }^{2}$ Department of Forest Botany and Tree Physiology, Georg-August-University of Goettingen, Germany \\ Correspondence: Markus Euring, Department of Molecular Wood Biotechnology and Technical Mycology, \\ Georg-August-University of Goettingen, Germany, E-Mail: meuring@gwdg.de
}

Received: February 17, 2017

Accepted: March 9, 2017

Online Published: March 27, 2017

doi:10.5539/jmsr.v6n2p69

URL: https://doi.org/10.5539/jmsr.v6n2p69

\begin{abstract}
Reducing $\mathrm{CO}_{2}$ emissions for the long term is an important issue in countering climate change. For this reason, the use of renewable construction materials inter alia wood-based materials is becoming increasingly important. Wood based materials often depend on petrochemical-based binding agents, most of which contain and emit formaldehyde. This causes environmental and health-related difficulties that could be rectified by avoiding the utilization of these adhesives. For this purpose, enzymatically bonded medium-density fiberboards (MDF) with a targeted raw density of $650 \mathrm{~kg} / \mathrm{m}^{3}$ and $750 \mathrm{~kg} / \mathrm{m}^{3}$ and high-density fiberboards (HDF) with a density of $900 \mathrm{~kg} / \mathrm{m}^{3}$ were produced in different thicknesses. Laccase-Mediator-System (LMS) was applied to manufacture the boards and to compare them to those glued with UF and inactivated laccase, respectively. These panels were tested in terms of their physical technical properties, such as internal bond strength (IB), modulus of rupture (MOR) and thickness swelling (TS) after $24 \mathrm{~h}$ immersion. The aim was to show the correlation between density and these properties for fiberboards bonded this way. Most panels meet the requirements of the European standard when LMS and UF-resin were used. The possibility to produce fiberboards bonded with alternative bonding agents opens up the way to alternative, innovative, healthy and environmental-friendly wood based products.
\end{abstract}

Keywords: MDF, HDF, Laccase, Laccase-Mediator-System, LMS

\section{Introduction}

In western nations an increasing environmental consciousness has been observed for the past decades, for example in Germany (BMUB, 2015). The material use of biomass offers the opportunity to instigate enormous reductions in greenhouse gas emissions if manufactured in an ecological way (Kok, 2002; Goverse et al., 2001). Using wood as a construction material creates several advantages. It is important to keep in mind that wood stores carbon during the trees' lifespan (Strasburger et al., 2014; Kok, 2002). This wood can be used as round wood, sawn wood and wood based panels to substitute conventional and energy-intensive materials such as concrete, steel and plastic (Kok, 2002). Wood based materials are produced through shredding wood and its reformation afterwards (Dunky, Niemz, 2002; Soiné, 1995; Lohmann, 2010). They may be classified based on the degree of reduction ratio (Niemz, 2012). Similar to solid wood, the wood based materials are near-natural and more $\mathrm{CO}_{2}$-neutral than other materials used for construction and furniture production (Kok, 2002; Goverse et al., 2001). The advantages of the manufactured wood materials are a higher isotropy, and increased homogeneous and insulating properties compared to solid wood (Barber, 1964; Niemz, 2012). Utilizing wood-based materials enables manifold applications because they enable production of materials with desired dimensions and properties, making the panel manufacturing one of the most important sectors of the wood industry (Soiné, 1995). Within the European wood based panel industry the particle board producers in 2014 showed the highest output with a volume of 29.0 million cubic meters. The second largest quantity was MDF production making up 14.8 million cubic meters which altogether covered around $75 \%$ of all wood based panels production (EPF, 2015). In contrast to particle boards, MDF are characterized by higher strength and surface-related properties as well as better profiling capability (Deppe, 1996). Furthermore, it is possible to produce fiberboards of up to $1.5 \mathrm{~mm}$ thickness (Ambrozy, 2005).

At the beginning of the MDF production process fibers are obtained by debarking and chipping of logs. Afterwards the chips are cleaned and refined into pulp by means of thermo-mechanical pulping (TMP). To produce fiber 
boards two different procedures are known. In the wet process water as well as glues, dyes and other agents are blended with the TMP fibers in chests. From there the fiber suspension is transferred to a screening belt where the web forming is done by drainage, suction and pressing. Hereafter the fiber fleece is dried to produce low density insulation boards or gets hot pressed to obtain HDF (Dunky, 2002). However, the wet process is no longer applied due to low strength properties, and inhomogeneous density distribution of the boards and environmental concerns regarding their production (Deppe, 1996). In contrast to the wet process the TMP fibers are glued in a blowline- or a blendersystem and get dried immediately after by a tube dryer to a moisture content of 9 - Usually $11 \%$ (Dunky, 2002; Pizzi, 2003). The web forming uses a pneumatic or mechanical method before the fiber fleece is hot pressed in continuous presses (Dunky, 2002). In the meantime the dry process is predominantly being used to produce fiber boards because, amongst other reasons, of the fact that it entails economic and ecological advantages when taking into consideration, for example, drying time (Euring, 2008; Makas, 2012).

Adhesives applied in the wood products industry are usually amino resins based on formaldehyde reacting with amino groups from different sources, such as urea (UF) or melamine (MF) (Pizzi, Mittal 2003). UF- and MF resins or combinations thereof, e.g. urea-melamine formaldehyde (MUF), are utilized in around $90 \%$ of all wood based products (Niemz, 2012). Also phenolic resins generated by the reaction of phenol and formaldehyde (PF), are in use. On the one hand, technical as well as economic reasons are motivations to use resins formaldehyde containing, especially UF (Zeppenfeld, 2005), while on the other, there are environmental and health-related concerns when considering the formaldehyde emissions of wood based products during and after being hot pressed. In addition the vulnerability for hydrolysis of cured UF glue joints leads to formaldehyde release (Dunky, 2002). In the European Union formaldehyde is considered to be carcinogenic, mutagenic or toxic to reproduction (EU 605/2014 2014). To circumvent the difficulties with the conventional synthetic binders mentioned above, and to offer a complete environmental-friendly solution, it might be an approach to use adhesives which contain no harmful substances. Alternative binders are based on various natural sources, such as tannins, lignins, animal and plant proteins or carbohydrate polymers, or through enzymatic activity (Dunky, 2002). Using them could be advantageous with regards to the fact that they allow a virtually full organic manufacturing of wood based products together with being completely recyclable (Habenicht, 2009). Following EURING (2008), in the present work enzymatically bonded fiber boards have been produced using the woods natural inherent glue, the lignin. During pulping, the lignin of the cell walls middle lamella becomes plasticized and the single fibers get separated (Dunky, 2002; Stokke et al., 2014). The cells obtained in this way are coated with a resolidified lignin layer that serves as substrate to be oxidated by the subsequently applied laccase-mediator-system (LMS) (Hüttermann, 1993; d'Acunzo et al., 2002; Kües et al., 2007; Widsten, 2008). Applying LMS to produce MDF or HDF has the intention to activate the lignin, i.e. to start a radically induced depolymerisation within the lignin of the cell wall (Widsten et al., 2004; Euring, 2008). Due to its oxidation potential the lignin-degrading enzyme laccase is hardly able to oxidize lignin except for its phenolic groups and because of its size laccase is scarcely able to penetrate the wood cell wall (Rochefort et al., 2004; Sixta, 2006). Adding a mediating small redox molecule copes with both of these aspects: The oxidation of a broader array of lignin components works much deeper in the cell walls affected because of the mediators minute size and its higher redox potential (Sixta, 2006; Rochefort et al., 2004). The application of such LMS was first used for oxidative reactions of non-phenolic compounds of the lignin in the 1990s (Bourbonnais, 1990). This information provides an application for delignification in the pulping process (Rochefort et al., 2004). Lignin fractions created this way polymerize while the fiber web is hot pressed to MDF or HDF, because the radicals decay under the influence of heat (Widsten, 2002).

The raw density is one of the most important features of wood and wood-based materials, substantially influencing their physical-technological belongings (Niemz, 2012; Boehme, 1991; Vorreiter, 1958). The density is calculated from the mass in relation to the volume (Lohmann, 2010). As raw density rises, strengths, hardness, elastic properties, coefficient of thermal conductivity and swelling increase also (Lohmann, 2010; Niemz, 2012; Maas, 2013; Schmidt, 2013; Roffael, 1972; May, 1978).

In the present work, MDF as well as HDF with a raw density of 650 and $750 \mathrm{~kg} / \mathrm{m}^{3}$ and $900 \mathrm{~kg} / \mathrm{m}^{3}$ respectively, were produced and their most important properties; internal bond strength (IB), the modulus of rupture (MOR) and thickness swelling after $24 \mathrm{~h}$ immersion were tested.

The boards vary in thickness $(6 \mathrm{~mm}$ and $12 \mathrm{~mm})$ and different binding agents were applied, such as inactivated laccase, laccase, laccase-mediator-systems and UF resin. The purpose of this work is to show if the different binder systems used cause differences in properties of boards of the same density and thickness. 


\section{Materials and Methods}

\subsection{Softwood Fibers}

The wood fibers used, were defibrated by Steico SE (Feldkirchen, Germany) via thermo-mechanical pulping (TMP). The fiber blend consisted of 90\% Pinus sylvestris wood and 10\% Pinus radiata wood.

\subsection{Urea-Formaldehyde Resin}

The commercial UF resin K350 with a molar ratio of 1.00:1.16 urea:formaldehyde and a solid content of $68 \%$ from BASF SE (Ludwigshafen am Rhein, Germany) was used as binder for conventional manufactured reference boards.

\subsection{Mc Ilvaine Buffer}

In order to optimize enzymatic reaction a slightly acidic McIlvaine buffer-system $(\mathrm{pH}=6)$ was used as the basic component of laccase-mediator-system (LMS) (Euring 2008). It consisted of $0.2 \mathrm{M}$ di-potassium hydrogen phosphate $\left(\mathrm{K}_{2} \mathrm{HPO}_{4}\right)$ and $0.1 \mathrm{M}$ citric acid $\left(\mathrm{C}_{6} \mathrm{H}_{8} \mathrm{O}_{7}\right)$ from AppliChem $\mathrm{GmbH}$ (Darmstadt, Germany).

\subsection{Hydrophobic Agent}

In the present study Hydrowax of the type 138 from Sasol Corporation (Johannesburg, South Africa) was used to protect the fiber boards against moisture. It has a solid content of $60 \%$.

\subsection{Laccase}

The commercial laccase Novozym 51003 from Novozym A/S (Bagsvaerd, Denmark) was used in the current investigation which was biotechnologically synthesized from Trametes vilosa in recombination with Aspergillus oryzae. The enzymatic activity was periodically determined according to the ABTS-Test method of Matsumura et al. (1986). On this occasion, the discoloration initiated by the oxidative reaction between $2,2^{\prime}$-azinobis-3-ethylbenzothiazoline-6-sulfonic and the enzyme, was investigated. The mean value of enzyme's activity was around $1100 \mathrm{U} / \mathrm{mL}$.

For reference purposes, laccase was inactivated by 10 minutes of cooking.

\subsection{Mediator}

The low molecular weight material, 4-hydroxybenzoic acid (HBA), with a chemical purity of $99 \%$, from Alfa Aesar GmbH \& Co. KG (Karlsruhe, Germany), acted as a mediator to improve the enzymatic reaction of the laccase-mediator-system (LMS).

\subsection{Manufacturing of Medium Density Fiberboards in Pilot Scale}

Fiber boards to be tested were produced at the institute's own fiberboard pilot plant (Binos GmbH, Springe, Germany). For each manufacturing process a total fiber content of $15 \mathrm{~kg}$ absolutely dry (atro) wood fibers was used. The first step in the work was gluing the fibers. In order to do this, fiber material was evenly sprayed with 7.5 L laccase solution (L), 7.5 L laccase-mediator-system (LMS), both of them with an enzymatic activity of $100 \mathrm{U} / \mathrm{mL}$ or $10 \%$ urea formaldehyde (UF). The LMS variations had a mediator concentration of $10 \mathrm{mM}$. All quantities are referred to absolutely dry wood fibers. For reference purposes, wood fibers were compared blended only with buffer, buffer and mediator, buffer in combination with boiled, inactivated laccase and buffer in conjunction with boiled, inactivated laccase and mediator. The treatments were repeated three times and for each variant $15 \mathrm{MDF} / \mathrm{HDF}$ were produced. In total, fiber boards with different raw densities $\left(650,750\right.$ and $\left.900 \mathrm{~kg} / \mathrm{m}^{3}\right)$ were manufactured. In addition, the boards were fabricated with different thicknesses ( 6 and $12 \mathrm{~mm}$ ).

In order to protect the fiber boards from moisture absorption, $1 \%$ hydrowax was used for all treatments.

The gluing occurred in the horizontal blender unit at room temperature $\left(22^{\circ} \mathrm{C}\right)$. As a part of this process, three injectors sprayed binding agent onto the fibers. After gluing, the drying took place in the tube dryer via airflow with a temperature of $120^{\circ} \mathrm{C}$ and at this point the moisture content of the fibers was reduced to approximately $8 \%$. Afterwards, a cyclone spread the fiber material onto a conveyer belt which collected and sent it forward to the fiber bunker. From there the fibers were strewn as a thick and homogenous fiber mat onto the form conveyer through the integrated spreader unit. This was followed by the manually pre-pressing procedure, without heat application, to prepare the fiber fleece for subsequent curing via a hot press (Siempelkamp GmbH \& Co. KG, Krefeld, Germany) at $200{ }^{\circ} \mathrm{C}$ which lasted $12 \mathrm{~s}$ per $1 \mathrm{~mm}$ board thickness. The final work processes were at first a 24-hour conditioning in a climate chamber at $20 \pm 2{ }^{\circ} \mathrm{C}$ and $65 \pm 5 \%$ humidity followed by grinding off the anti-adhesive surface film, and finally manufacturing of the respective specimen. Physical-technological properties such as internal bond strength (IB), modulus of rupture (MOR) and thickness swelling (TS) were tested according to European Norms EN 319, EN 310, and EN 317 (European Committee for Standardization [CEN], 1993a, 1993b, 
2003). Therefore the test specimens for IB and TS were prepared measuring $50 \times 50 \mathrm{~mm}$. In order to determine the MOR, samples were produced with a width of $50 \mathrm{~mm}$ and a length depending on the respective thickness of the $\mathrm{MDF} / \mathrm{HDF}$.

In this case a universal test machine of the type Zwick/Roell ZO10 (Zwick/Roell Corporation, Ulm, Germany) was used which operated with the program TestXpert (Version 10.1.1 from Zwick/Roell).

\section{Results and Discussion}

\subsection{Internal Bond}

\subsubsection{Internal Bond Strength}

Present IB tests for $6 \mathrm{~mm}$ and $12 \mathrm{~mm}$ thick MDF were conducted according to the standard EN 319 (1993) and had to fulfill prescribed values of EN 622-5 (2010) respectively. Six samples of each MDF were analyzed.

Figure 1 displays the IB of MDF with a thickness of $6 \mathrm{~mm}$ pressed at $12 \mathrm{~s} / \mathrm{mm}$ and various raw densities, bonded with inactivated laccase and laccase compared to laccase-mediator-system and urea formaldehyde. The standard requires values of at least $0.65 \mathrm{~N} / \mathrm{mm}^{2}$ to be achieved. For further reference purposes, MDF were also produced in thicknesses of $6 \mathrm{~mm}$ and $12 \mathrm{~mm}$ from fibers treated with buffer, buffer and mediator, buffer in combination with boiled, inactivated laccase and buffer in conjunction with boiled, inactivated laccase and mediator (data not shown as no differences have been detected within reference samples and control).

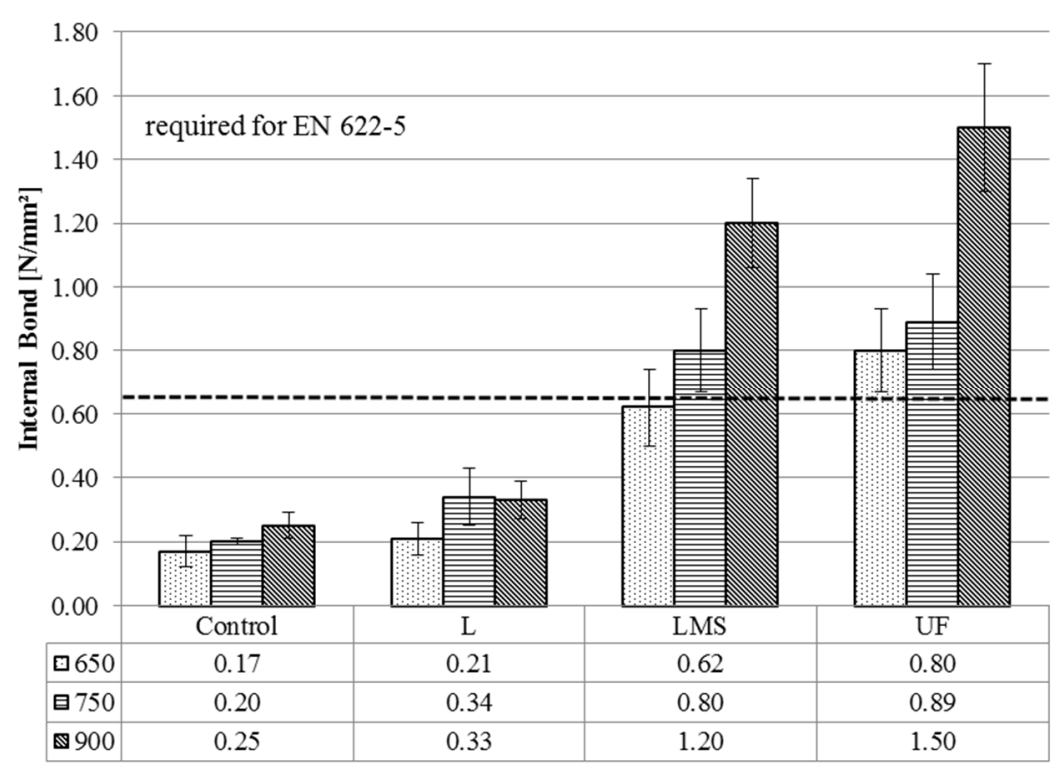

Figure 1. IB results for MDF specimen with a thickness of $6 \mathrm{~mm}$ and different raw densities of 650,750 , and $900 \mathrm{~kg} / \mathrm{m}^{3}$. Control, inactivated laccase; L, laccase; LMS, laccase-mediator-system; UF, urea formaldehyde. Each result is presented as an average with eliminated outliers of three repetitions. The standard variance is illustrated as error bar

By using UF as binder for MDF IBs of $0.80,0.89$ and $1.50 \mathrm{~N} / \mathrm{mm}^{2}$ were obtained. However, LMS samples using HBA as mediator achieved values of $0.62,0.80$ and $1.20 \mathrm{~N} / \mathrm{mm}^{2}$ and almost fulfilled the requirements of EN 319 (1993) of all three raw densities. These performed with the second best results. The efficiency of this mediator has already been demonstrated in previous reports (Euring, 2008; Kirsch et al., 2015; Euring et al., 2011). Laccase obtained IB values of $0.21,0.34$ and $0.33 \mathrm{~N} / \mathrm{mm}^{2}$ merely. When using inactivated laccase as control specimen, IB figures of 0.17 and 0.20 and $0.25 \mathrm{~N} / \mathrm{mm}^{2}$ were obtained. Schulte and Frühwald (1996) have found a correlation between minimum density and IB of MDF bonded with UF and Polyurethanes (PUR), which vary in thickness and density.

Similar to previous results IB tests were carried out according to the standard EN 319 (1993) and EN 622-5 (2010). In this case prescribed values of at least $0.60 \mathrm{~N} / \mathrm{mm}^{2}$ with regards to its thickness have to be achieved. Six 
specimens of each MDF have also been analyzed. Figure 2 demonstrates the IB of a $12 \mathrm{~mm}$ thick MDF pressed at $12 \mathrm{~s} / \mathrm{mm}$ and various raw densities bonded with inactivated laccase, laccase, LMS and likewise with UF.

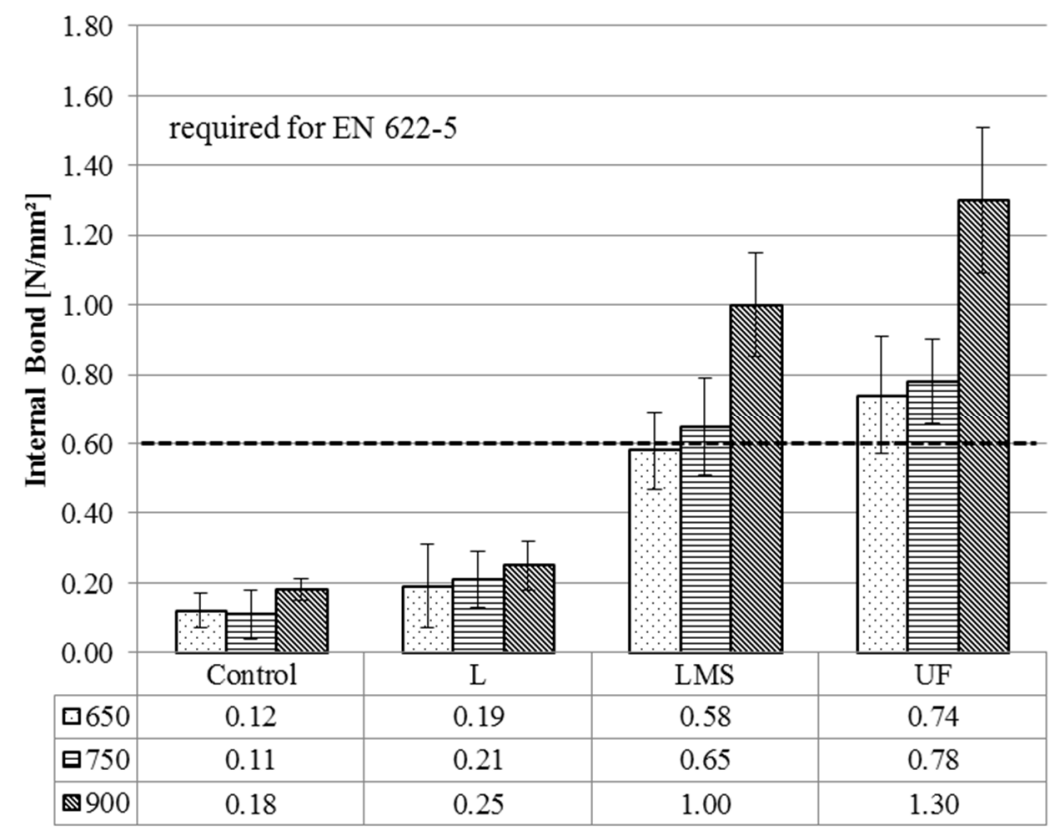

Figure 2. IB results for MDF specimen with a thickness of $12 \mathrm{~mm}$ and different raw densities of 650, 750, and $900 \mathrm{~kg} / \mathrm{m}^{3}$. Control, inactivated laccase; L, laccase; LMS, laccase-mediator-system; UF, urea formaldehyde. Each result is presented as an average with eliminated outliers of three repetitions. The standard variance is illustrated as error bar

The LMS specimen using HBA as mediator achieved values of $0.58,0.65$ and $1.00 \mathrm{~N} / \mathrm{mm}^{2}$ and almost fulfilled the requirements of EN 319 (1993) in all three raw densities and performed with the second best results.

This outcome shows that the IB of enzymatic bonded MDF behaves similarly to enzymatically treated thinner fiber boards. By using UF as binding agent for MDF IB numbers of $0.74,0.78$ and $1.30 \mathrm{~N} / \mathrm{mm}^{2}$ were attained. When comparing enzymatically bonded with conventionally bonded MDF, it becomes obvious that they behave in the same way relevant to their thickness and raw density. Specimens bonded solely with laccase achieved IB values of $0.19,0.21$ and $0.25 \mathrm{~N} / \mathrm{mm}^{2}$ and did not meet the standard. By using inactivated laccase, values of 0.12 and 0.11 and $0.18 \mathrm{~N} / \mathrm{mm}^{2}$ were accomplished. The results presented in Figure 1 and 2 clearly show the highest IB values for thinner boards in general. There is no difference between the enzymatically and conventionally bonded MDF in relation to the behavior of enhanced IB values. However, it has to be mentioned that improved IB numbers are expected in connection with increasing raw densities.

Increasing the amount of mediator does not lead to further improvements in internal bond strength. (Euring 2008). Another important influencing factor is the use of hydrophobic agents for MDF production (Back 1987). Following Felby et al. (2002), the enzymatic treatment of TMP wood fibers combined with paraffin wax as hydrophobic agent, impacts IB values disadvantageously.

\subsection{Modulus of Rupture}

Specimens for MOR were investigated by a three-point bending test regarding to EN 310 (1993). According to standard EN 622-5 (2010), MOR values of at least $23 \mathrm{~N} / \mathrm{mm}^{2}$ are required for boards with a thickness of $6 \mathrm{~mm}$. For each produced MDF, at least three samples were tested, and the values were averaged. Figure 3 shows the MOR of MDF with a thickness of $6 \mathrm{~mm}$, a pressing time of $12 \mathrm{~s} / \mathrm{mm}$ and various raw densities bonded with inactivated laccase, laccase, LMS and UF. In addition reference MDF were also produced in thicknesses of $6 \mathrm{~mm}$ and $12 \mathrm{~mm}$ from fibers treated with buffer, buffer and mediator, buffer in combination with boiled, inactivated laccase and buffer in conjunction with boiled, inactivated laccase and mediator (data not shown as no differences have been detected within reference samples and control). 


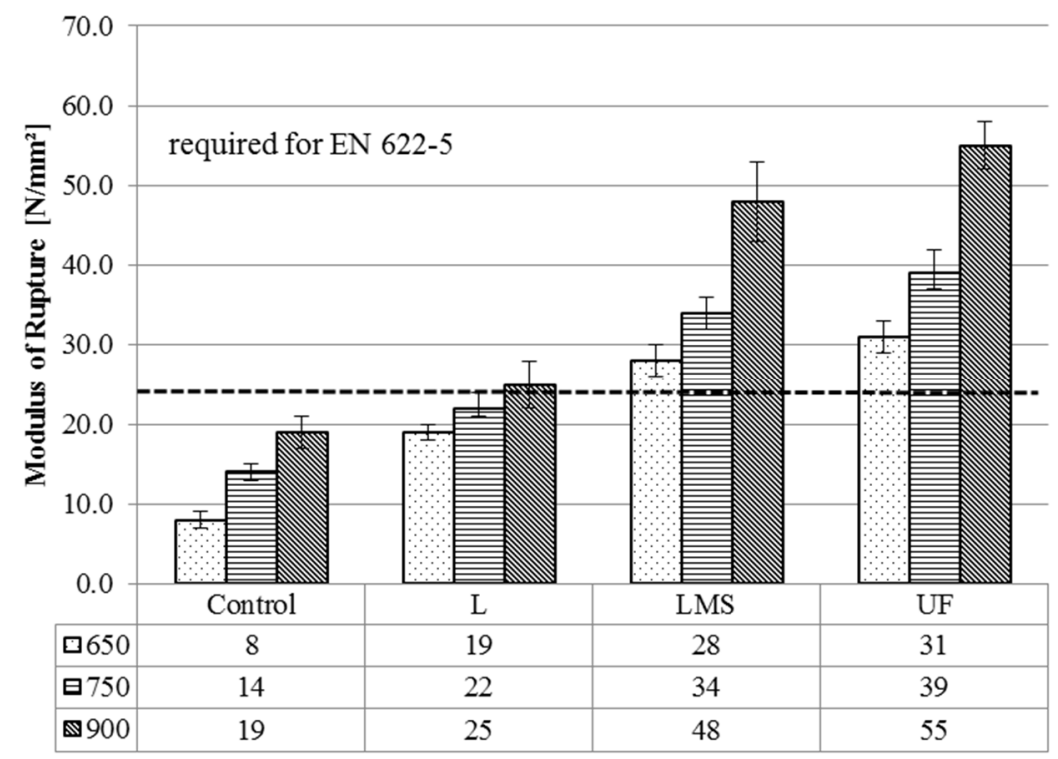

Figure 3. MOR results for MDF specimen with a thickness of $6 \mathrm{~mm}$ and different raw densities of 650,750 , and $900 \mathrm{~kg} / \mathrm{m}^{3}$. Control, inactivated laccase; L, laccase; LMS, laccase-mediator-system; UF, urea formaldehyde. Each result is presented as an average with eliminated outliers of three repetitions. The standard variance is illustrated as error bar

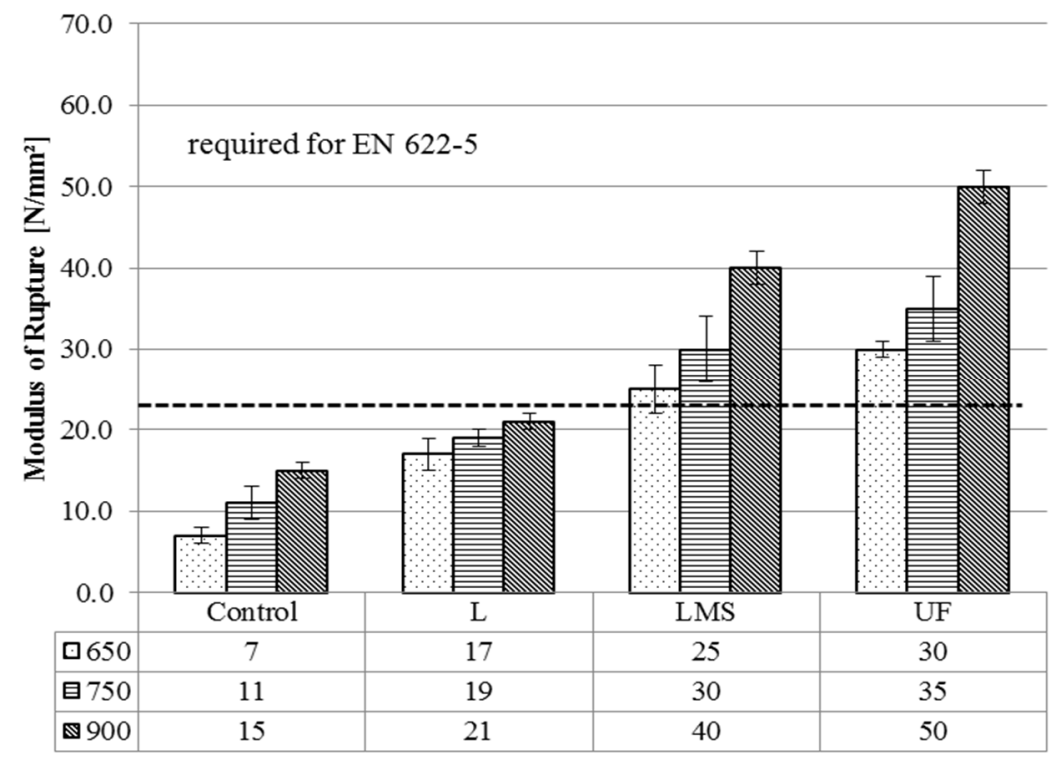

Figure 4. MOR results for MDF specimen with a thickness of $12 \mathrm{~mm}$ and different raw densities of 650, 750, and $900 \mathrm{~kg} / \mathrm{m}^{3}$. Control, inactivated laccase; L, laccase; LMS, laccase-mediator-system; UF, urea formaldehyde. Each result is presented as an average with eliminated outliers of three repetitions. The standard variance is illustrated as error bar

In the MDF specimen using LMS for bonding, values of 28,34 and $48 \mathrm{~N} / \mathrm{mm}^{2}$ are obtained. This fulfilled the requirements of EN 310 (1993) in all three bulk densities and gave the second best results. When using laccase MOR values of 19,22 and $25 \mathrm{~N} / \mathrm{mm}^{2}$ were achieved and partially fulfilled the requirement of the standard. When using inactivated laccase and buffer for control, values of 8 and 14 and $19 \mathrm{~N} / \mathrm{mm}^{2}$ were obtained. Thus better results were achieved by adding laccase or laccase in conjunction with mediators in general. By using $10 \%$ UF as binding agent for MDF the highest MOR numbers of 31, 39 and $55 \mathrm{~N} / \mathrm{mm}^{2}$ were attained. 
With regards to standard EN 622-5 (2010), MOR values of at least $22 \mathrm{~N} / \mathrm{mm}^{2}$ are required. At least three specimens were tested per MDF and the values were averaged. Figure 4 displays the MOR of MDF with a thickness of $12 \mathrm{~mm}$ and a pressing time of $12 \mathrm{~s} / \mathrm{mm}$ and various raw densities bonded with inactivated laccase, laccase, LMS and UF. Boards were also produced from fibers exclusively treated with buffer (data not shown).

In MDF samples using LMS as binding agent, values of 25,30 and $40 \mathrm{~N} / \mathrm{mm}^{2}$ are obtained and fulfilled the requirements of EN 310 (1993) in all three bulk densities and gave the second best results. Using solely laccase as binding agent, MOR values of 17,19 and $21 \mathrm{~N} / \mathrm{mm}^{2}$ were realized which don't meet the standard. When using inactivated laccase, values of 7 and 11 and $15 \mathrm{~N} / \mathrm{mm}^{2}$ were obtained. By using UF as binder for MDF the highest MOR numbers of 30, 35 and $50 \mathrm{~N} / \mathrm{mm}^{2}$ were reached, and which fulfil the requirement. When looking at Figure 3 and 4, it can be observed that higher bulk densities involve enhanced MOR values in all cases.

\subsection{Thickness Swelling}

TS tests were carried out after $24 \mathrm{~h}$ of immersion in water according to standard EN 317 (1993), and oriented towards EN 622-5 (2010) requirements, samples can exhibit a maximum swelling behavior of $17 \%$ for $6 \mathrm{~mm}$ and $15 \%$ for $12 \mathrm{~mm}$ thickness. For each MDF at least six samples were analyzed.

To allow an easier comparison, the following table displays the swelling behavior of MDF pressed at $12 \mathrm{~s} / \mathrm{mm}$ and different raw densities bonded with inactivated laccase, laccase, LMS and UF. For further reference purposes, MDF were also produced in thicknesses of $6 \mathrm{~mm}$ and $12 \mathrm{~mm}$ from fibers treated with buffer, buffer and mediator, buffer in combination with boiled, inactivated laccase and buffer in conjunction with boiled, inactivated laccase and mediator (figures not shown as no differences have been detected within reference samples and control).

Table 1. TS results for MDF specimen with a thickness of 6 and $12 \mathrm{~mm}$ and different raw densities of 650,750 , and $900 \mathrm{~kg} / \mathrm{m}^{3}$. Control, inactivated laccase; L, laccase; LMS, laccase-mediator-system; UF, urea formaldehyde. Each result is presented as an average with eliminated outliers of three repetitions

Thickness swelling [\%]

\begin{tabular}{|c|c|c|c|c|}
\cline { 3 - 5 } \multicolumn{2}{c|}{} & \multicolumn{3}{|c|}{ Bulk density $\left[\mathrm{kg} / \mathrm{m}^{3}\right]$} \\
\hline Sample & Thickness [mm] & 650 & 750 & 900 \\
\hline \multirow{2}{*}{ Control } & 6 & $56( \pm 2)$ & $55( \pm 1)$ & $48( \pm 3)$ \\
\cline { 2 - 5 } & 12 & $65( \pm 3)$ & $74( \pm 4)$ & $49( \pm 2)$ \\
\hline \multirow{2}{*}{ Laccase } & 6 & $49( \pm 2)$ & $41( \pm 2)$ & $34( \pm 4)$ \\
\cline { 2 - 5 } & 12 & $51( \pm 1)$ & $54( \pm 3)$ & $41( \pm 4)$ \\
\hline \multirow{2}{*}{ LMS } & 6 & $20( \pm 1)$ & $17( \pm 1)$ & $17( \pm 1)$ \\
\cline { 2 - 5 } & 12 & $22( \pm 2)$ & $21( \pm 2)$ & $14( \pm 2)$ \\
\hline \multirow{2}{*}{ UF } & 6 & $17( \pm 0.8)$ & $15( \pm 0.5)$ & $16( \pm 1)$ \\
\cline { 2 - 5 } & 12 & $16( \pm 0.5)$ & $12( \pm 1)$ & $10( \pm 1)$ \\
\hline
\end{tabular}

UF and LMS bonded boards achieved the lowest figures. Moreover, the results indicated that the swelling percentage of the produced MDF after $24 \mathrm{~h}$ immersion, behaved inversely proportional to their density and proportional to their thickness. Laccase bonded MDF swelled almost twice as much as those where LMS has been applied. The MDF bonded with inactivated laccase have shown the highest average in thickness swelling of up to $74 \%$ for the boards with a density of $750 \mathrm{~kg} / \mathrm{m}^{3}$ and $12 \mathrm{~mm}$ thickness.

The results obtained in this work allow characterizing LMS-bonded MDF in pilot scale as a successful approach to produce binderless, high-quality products for general, interior use. It could be shown that by means of LMS boards can reach properties comparable to UF-bonded ones. Moreover, the outcomes demonstrate once more the superiority of LMS against the application of mere laccase, due to its higher oxidation potential towards lignins. For IB LMS-bonded fiberboards in this case could achieve three to four times higher values across all panel types varying in density and thickness. That also applies for MOR and TS, where almost twice as favorable properties were measured. This work also confirms for LMS-bonded MDF the positive correlation between density and strength properties, which is reported in literature, e.g. DUNKY \& NIEMZ (2002), FelBY et al. (2002). This shows that MDF bonded only with laccase achieve results that are comparable to UF-bonded boards. However, in those cases the pressing time of $25 \mathrm{~s} / \mathrm{mm}$ was considerably longer than in the present work. Also WIDSTEN et al (2004) found a correlation between the density of laccase bonded MDF and their mechanical properties, although that work was focused on how the defibration temperature affects MDF. 
Further improvements should be made considering the reduction of pressing time to make the production process more applicable for future industrial scale. Usually industrially manufactured MDF require $8.5-11.0 \mathrm{~s} / \mathrm{mm}$ board thickness where UF is used as a binder (Dunky, Niemz 2002).

\section{Conclusion}

Enzymatically bonded MDF and HDF of $650 \mathrm{~kg} / \mathrm{m}^{3}, 750 \mathrm{~kg} / \mathrm{m}^{3}$ and $900 \mathrm{~kg} / \mathrm{m}^{3}$ density and a thickness of $6 \mathrm{~mm}$ and $12 \mathrm{~mm}$ have been produced and tested in the present work. The results prove clearly the correlation between the boards' densities and physical technical properties, such as IB and MOR and TS on the one hand and their slight decrease when the boards' thickness is doubled on the other. Furthermore, it becomes apparent that from the different enzymatic binders only the LMS is a suitable method to meet the requirements of EN 622-5 and leads to panel property values comparable to UF. These enzymatic bonded fiberboards can be manufactured within an appropriate hot pressing time of $12 \mathrm{~s} / \mathrm{mm}$ at pilot scale. Further development needs to be conducted in order to make the production process more applicable for industrial scale production, especially through shortening the pressing time even more.

\section{Acknowledgements}

This work was supported by the Deutsche Forschungsgemeinschaft (DFG) grant EU 124/2-2 to Markus Euring.

\section{References}

Ambrozy, H. G., \& Giertlová, Z. (2005). Planungshandbuch Holzwerkstoffe. Technologie - Konstruktion Anwendung. Wien u.a.: Springer.

Back, E. L. (1987). The Bonding Mechanism in Hardboard Manufacture Review Report. Holzforschung, 41(4), 247-258. http://dx.doi.org/10.1515/hfsg.1987.41.4.247

Barber, N. F., \& Meylan, B. A. (1964). The Anisotropic Shrinkage of Wood. A Theoretical Model. Holzforschung, 18(5), 146-156. http://dx.doi.org/10.1515/hfsg.1964.18.5.146

Boehme, C. (1991). Einfluß der Rohdichte und des Hydrophobierungsmittelanteils auf die Biege- und Querzugfestigkeit von Spanplatten. Holz als Roh-und Werkstoff, 49(6), 242. http://dx.doi.org/10.1007/ BF02627546.

Bourbonnais, R., \& Paice, M. G. (1990). Oxidation of non-phenolic substrates. In FEBS Letters, 267(1), 99-102. http://dx.doi.org/10.1016/0014-5793(90)80298-W.

d'Acunzo, F., Galli, C., \& Masci, B. (2002). Oxidation of phenols by laccase and laccase-mediator systems. In European Journal of Biochemistry, 269(21), 5330-5335. http://dx.doi.org/10.1046/j.1432-1033.2002. 03256.x.

Deppe, H.-J., \& Ernst, K. (1996). Mitteldichte Faserplatten. MDF. Stuttgart: DRW-Verl.

Dunky, M., \& Niemz, P. (Eds.) (2002). Holzwerkstoffe und Leime. Technologie und Einflussfaktoren. 1. Aufl. Berlin: Springer.

EPF. (2015). European Panel Federation Annual Report 2014 - 2015 (pp. 43-52).

EU 605/2014. (2014). Verordnung (EU) Nr. 605/2014 der Kommission vom 05. Juni 2014 zur Änderung der Verordnung (EG) Nr. 1272/2008/EG des Europäischen Parlaments und des Rates über die Einstufung, Kennzeichnung und Verpackung von Stoffen und Gemischen zwecks Einfügung von Gefahren- und Sicherheitshinweisen in kroatischer Sprache und zwecks Anpassung an den technischen und wissenschaftlichen Fortschritt, Bundesanstalt für Arbeitsschutz und Arbeitsmedizin, (www.reach-clp-biozid helpdesk.de).

Euring, M. (2008). Einsatz von Mediatoren bei der Enzymatischen Aktivierung der Fasereigenen Bindekräfte zur Herstellung von Enzymgebundenen, Bindemittelfreien Holzwerkstoffen. Doctoral Thesis: Georg-August-Universität, Göttingen, Germany.

Euring, M., Rühl, M., Ritter, N., Kües, U., \& Kharazipour, A. (2011). Laccase mediator systems for eco-friendly production of medium-density fiberboard (MDF) on a pilot scale. Physicochemical analysis of the reaction mechanism. In Biotechnology Journal, 6(10), 1253-1261. http://dx.doi.org/10.1002/biot.201100119.

Euring, M., Trojanowski, J., Horstmann, M., \& Kharazipour, A. (2012). Studies of enzymatic oxidation of TMP-fibers and lignin model compounds by a Laccase-Mediator-System using different $14 \mathrm{C}$ and $13 \mathrm{C}$ techniques. In Wood Sci Technol, 46(4), 699-708. http://dx.doi.org/10.1007/s00226-011-0439-6. 
Felby, C., Hassingboe, J., \& Lund, M. (2002). Pilot-scale production of fiberboards made by laccase oxidized wood fibers. Board properties and evidence for cross-linking of lignin. In Enzyme and Microbial Technology, 31(6), 736-741. http://dx.doi.org/10.1016/S0141-0229(02)00111-4.

Goverse, T., Hekkert, M. P., Groenewegen, P., Worrell, E., \& Smits, R. E. H. M. (2001). Wood innovation in the residential construction sector; opportunities and constraints. In Resources, Conservation and Recycling, 34(1), 53-74. http://dx.doi.org/10.1016/S0921-3449(01)00093-3.

Habenicht, G. (2009). Kleben. Grundlagen, Technologien, Anwendungen. 6., aktualisierte Aufl. Berlin, Heidelberg: Springer Berlin Heidelberg (VDI-Buch). Retrieved from http://dx.doi.org/10.1007/978-3-540 $-85266-7$.

Hüttermann, A., \& Kharazipour, A. (Eds.) (1993). Die pflanzliche Zellwand als Vorbild für Holzwerkstoffe, naturorientierte Herstellung von Span- und Faserplatten. Stand der Technik und Perspektiven. Frankfurt a. M., Germany: J. D. Sauerländer's Verlag.

Kirsch, A., Euring, M., \& Ostendorf, K. (2015). Oxygen Consumption of Laccase-Mediator-Systems (LMS). In Journal of Materials Science Research, 4(3), 49. http://dx.doi.org/10.5539/jmsr.v4n3p49.

Kirsch, A., Ostendorf, K., Kharazipour, A., \& Euring, M. (2016). Phenolics as Mediators to Accelerate the Enzymatically Initialized Oxidation of Laccase-Mediator-Systems for the Production of Medium Density Fiberboards. BioResources, 11(3), 7091-7101. http://dx.doi.org/10.15376/biores.11.3.7091-7101

Kok, M. T. J. (2002). Global warming and social innovation. The challenge of a climate-neutral society. Retrieved from http://search.ebscohost.com/login. aspx?direct=true\&scope=site\&db=e000xat\&AN=452762

Kües, U., Bohn, C., Euring, M., Müller, C., Polle A., \& Kharazipour, A. (2007). Enzymatically Modified Wood in Panel Board Production. In Ursula Kües (Ed.), Wood production, wood technology, and biotechnological impacts. Göttingen, Göttingen: Univ.-Verl. Göttingen; Niedersächsische Staats-und Universitätsbibliothek (pp. 433-467).

Lohmann, U., \& Blosen, M. (2010). Holzlexikon. Das Standardwerk für die Holz- und Forstwirtschaft. 4. Aufl. Hamburg: Nikol.

Maas, A. (2013). Wärmeschutz. In Peter Häupl, Wolfgang M. Willems (Eds.), Lehrbuch der Bauphysik. Schall Wärme - Feuchte - Licht - Brand - Klima. 7., vollst. überarb. und aktualisierte Aufl. Wiesbaden: Springer Vieweg (Lehrbuch).

Makas, M. (2012). Holzfaserdämmstoffe - Stand heute und Anforderungen in der Zukunft. In Tagungsband zum 15. Holztechnologischen Kolloquiums, Dresden 2012.

Matsumura, E., Yamamoto, E., Numata, A., Kawano, T., Shin, T., \& Murao, S. (1986). Structures of the Laccase-catalyzed Oxidation Products of Hydroxy-benzoic Acids in the Presence of ABTS [2,2'-Azino-di-(3-ethylbenzothiazoline-6-sulfonic Acid)]. In Agricultural and Biological Chemistry, 50(5), 1355-1357. http://dx.doi.org/10.1080/00021369.1986.10867576.

May, H.-A. (1978). Einflüsse von Rohdichte und Jahrringbreite auf das Quellungsverhalten von Fichten-und Kiefernholz. In Holz als Roh-und Werkstoff, 36(5), 199-202. http://dx.doi.org/10.1007/BF02614491

Niemz, P. (2012). Physik des Holzes. In André Wagenführ (Ed.), Taschenbuch der Holztechnik. 2., aktualisierte Aufl. München: Fachbuchverl. Leipzig im Carl-Hanser-Verl.

Niemz, P., \& Wagenführ, A. (2012). Werkstoffe aus Holz. In André Wagenführ (Ed.), Taschenbuch der Holztechnik. 2., aktualisierte Aufl. München: Fachbuchverl. Leipzig im Carl-Hanser-Verl.

Pizzi, A., \& Mittal, K. L. (Eds.) (2003). Handbook of Adhesive Technology, Revised and Expanded. 2nd ed. Hoboken: Taylor and Francis. Retrieved from http://search.ebscohost.com/login.aspx?direct=true\&scope $=$ site $\& d b=$ lebk $\& d b=$ labk\&AN=100996.

Rochefort, D., Leech, D., \& Bourbonnais, R. (2004). Electron transfer mediator systems for bleaching of paper pulp. In Green Chem., 6(1), 14. http://dx.doi.org/10.1039/b311898n

Roffael, E., \& Rauch, W. (1972). Einfluß der Rohdichte auf das Quellungsverhalten von phenolharzgebundenen Spanplatten. In Holz als Roh-und Werkstoff, 30(5), 178-181. http://dx.doi.org/10.1007/BF02614985

Schmidt, P. (2013). Bauphysik. In Konrad Zilch, Claus Jürgen Diederichs, Rolf Katzenbach, Klaus J. Beckmann (Eds.), Konstruktiver Ingenieurbau und Hochbau. Berlin, Heidelberg, s.l.: Springer Berlin Heidelberg. 
Schulte, M., \& Frühwald, A. (1996). Shear modulus, internal bond and density profile of medium density fibre board (MDF). In Holz als Roh- und Werkstoff, 54(1), 49-55. http://dx.doi.org/10.1007/s001070050132.

Sixta, H. (Ed.) (2006). Handbook of pulp. Wiley InterScience (Online service). Weinheim, Chichester: Wiley-VCH.

Soiné, H. (1995). Holzwerkstoffe. Herstellung und Verarbeitung ; Platten, Beschichtungsstoffe, Formteile, Türen, Möbel. Leinfelden-Echterdingen: DRW-Verl.

Stokke, D. D., Han, G. P., \& Wu, Q. L. (2014). Introduction to wood and natural fiber composites. Chichester, West Sussex, United Kingdom: Wiley (Wiley series in renewable resource).

Strasburger, E., Noll, F., Schimper, A. F. W., Kadereit, J. W., Körner, C., Kost, B., \& Sonnewald, U. (Eds.) (2014). Lehrbuch der Pflanzenwissenschaften. 37., vollst. überarb. u. akt. Aufl. Berlin: Springer Spektrum.

Vorreiter, L. (1958). Holztechnologisches Handbuch: G. Fromme.

Widsten, P., Tuominen, S., Qvintus-Leino, P., \& Laine, J. E. (2004). The influence of high defibration temperature on the properties of medium-density fiberboard (MDF) made from laccase-treated softwood fibers. In Wood Sci Technol, 38(7), 521-528. http://dx.doi.org/10.1007/s00226-003-0206-4

Widsten, P. (2002). Oxidative activation of wood fibers for the manufacture of medium-density fiberboard (MDF). Espoo: Helsinki University of Technology (Reports / Helsinki University of Technology, Laboratory of Paper Technology. Series A, 15).

Widsten, P., \& Kandelbauer, A. (2008). Laccase applications in the forest products industry. A review. In Enzyme and Microbial Technology, 42(4), 293-307. http://dx.doi.org/10.1016/j.enzmictec.2007.12.003.

Zeppenfeld, G., \& Grunwald, D. (2005). Klebstoffe in der Holz- und Möbelindustrie. 2., überarb. und erw. Aufl. Leinfelden-Echterdingen: DRW-Verl. Weinbrenner.

\section{Copyrights}

Copyright for this article is retained by the author(s), with first publication rights granted to the journal.

This is an open-access article distributed under the terms and conditions of the Creative Commons Attribution license (http://creativecommons.org/licenses/by/4.0/). 